Masato Sakayori • Masanori Kawahara $\cdot$ Kazuko Shiraishi

Tadashi Nomizu • Akira Shimada • Toshio Kudo

Rikiya Abe • Noriaki Ohuchi · Seiichi Takenoshita

Ryunosuke Kanamaru • Chikashi Ishioka

\title{
Evaluation of the diagnostic accuracy of the stop codon (SC) assay for identifying protein-truncating mutations in the BRCA1 and BRCA2 genes in familial breast cancer
}

Received: October 9, 2002 / Accepted: December 3, 2002

\begin{abstract}
Screening for protein-truncating mutations of the $B R C A 1$ and $B R C A 2$ genes is useful in genetic testing for familial breast cancer because, first, the methods are usually simple and not expensive, and second, the detected mutations indicate pathogenic mutations in general. We evaluated the diagnostic accuracy of the stop codon (SC) assay for detecting protein-truncating mutations in the $B R C A 1$ and $B R C A 2$ genes by comparing the results with DNA sequencing in samples from 29 patients with breast cancer from 24 Japanese families with a history of breast cancer. Protein-truncating mutations were detected in 5 of the 24 families $(20.8 \%$; two in the BRCA1 gene and three in the $B R C A 2$ gene). Among the 176 DNA fragments examined using the SC assay, the existence of three protein-truncating mutations (one in the BRCA1 gene and two in the BRCA2 gene) was predicted correctly by the assay. Only one reverse transcriptase-polymerase chain reaction fragment was positive for the SC assay but was negative using DNA sequencing. Our study showed clearly that the SC assay is sensitive ( 3 of $3,100 \%)$ and specific (172 of $173,99 \%)$ for detecting pathogenic protein-truncating mutations in the
\end{abstract}

M. Sakayori · M. Kawahara · K. Shiraishi $\cdot$ A. Shimada

R. Kanamaru $\cdot$ C. Ishioka $(\triangle)$

Department of Clinical Oncology, Institute of Development, Aging and Cancer, Tohoku University, 4-1 Seiryo-machi, Aoba-ku, Sendai 980-8575, Japan

Tel. +81-22-717-8547; Fax +81-22-717-8548

e-mail: chikashi@idac.tohoku.ac.jp

M. Kawahara $\cdot$ S. Takenoshita

Department of Surgery II, Fukushima Medical University School of Medicine, Fukushima, Japan

K. Shiraishi · N. Ohuchi

Division of Surgical Oncology, Tohoku University School of

Medicine, Sendai, Japan

T. Nomizu

Department of Surgery, Hoshi General Hospital, Koriyama, Japan

T. Kudo

Cell Resource Center for Biomedical Research, Institute of

Development, Aging and Cancer, Tohoku University, Sendai, Japan

R. Abe

Tohoku Familial Tumor Association, Koriyama, Japan
$B R C A 1$ and $B R C A 2$ genes, and that it could be useful for screening larger populations.

Key words Stop codon assay - Familial breast cancer . $B R C A 1 \cdot B R C A 2 \cdot$ Genetic testing

\section{Introduction}

Mutations in the BRCA1 and BRCA2 genes have been linked with susceptibility to breast and ovarian cancer, and patients who carry germline mutations of these genes are at high risk of developing these cancers. Accumulating evidence has shown that the BRCA1 and BRCA2 genes together are likely to account for the majority $(\sim 80 \%)$ of familial breast and ovarian cancers with at least four patients with breast cancer (Ford et al. 1998), and for approximately $50 \%$ of those with three or more female patients with breast or ovarian cancer, although the proportion of these mutations varies among populations (Szabo and King 1997). Although the cumulative risk of breast cancer in female carriers in the families with multiple cancer cases selected for linkage analysis was estimated to be $>80 \%$ by age 70 years (Easton et al. 1993), recent studies have shown that cumulative breast cancer risk in $B R C A 1$ or $B R C A 2$ mutation carriers varies widely depending on the population studied (BRCA1, 47\%-87\%; BRCA2, 37\%-84\%) (Anglian Breast Cancer Study Group 2000; Ford et al. 1998; Narod et al. 1995; Neuhausen 1999; Rebbeck 1999; Struewing et al. 1997; Thorlacius et al. 1998). These observations have been derived mainly from Western countries; thus, the data are not always thought to be applicable to the Japanese population. Several Japanese studies have shown that the contribution of the BRCA1 and $B R C A 2$ genes to Japanese familial breast and ovarian cancers $(10 \%-30 \%)$ seems to be the same as that in Caucasian and Ashkenazi Jewish populations, although fewer patients have undergone BRCA testing (Anglian Breast Cancer Study Group 2000; Ikeda et al. 2001; Inoue et al. 1995; Inoue et al. 1997; Shih et al. 2002; Takano et al. 1997). 
A rapid, simple, and accurate screening method is needed to accelerate genetic testing for familial breast and ovarian cancers because the two BRCA genes have large coding sequences that consist of 48 exons to be sequenced (Miki et al. 1994; Tavtigian et al. 1996; Wooster et al. 1995); therefore, detection of mutations using DNA sequencing analysis is labor intensive and expensive. Furthermore, most of the current screening methods, such as singlestrand conformation polymorphism and denaturing high-performance liquid chromatography, detect not only pathogenic mutations but also several single-nucleotide polymorphisms (SNPs) (Kuklin et al. 1997; Orita et al. 1989; Xiao and Oefner 2001). In general, protein-truncating mutations of the $B R C A 1$ and $B R C A 2$ genes only provide reliable information for cancer-risk evaluation of patients and their family members because protein-truncating mutations theoretically eliminate the functional domain(s) of the gene product, although there is a carboxy-terminal nonsense mutation (K3326X) that is not disease associated (Mazoyer et al. 1996). None of the current methods discriminate missense mutations from nonpathogenic SNPs. Furthermore, more than $80 \%$ and $90 \%$ of reported $B R C A 1$ and $B R C A 2$ mutations, respectively, are protein-truncating mutations that were mapped broadly to the large (BRCA1, $5.6 \mathrm{~kb} ; B R C A 2,10.3 \mathrm{~kb}$ ) coding sequences (http://www. nhgri.nih.gov/Intramural_research/Lab_transfer/Bic/). Based on these findings, methods that only detect proteintruncating mutations have been used to screen $B R C A 1$ and $B R C A 2$ mutations. These methods include the protein truncation test (PTT) (Hogervorst et al. 1995; van der Luijt et al. 1994), also called the in vitro synthesized-protein assay (Powell et al. 1993), and the yeast-based stop codon (SC) assay (Ishioka et al. 1997). These techniques are used widely for genetic testing of other genes, including the $A P C$ gene, especially when most of the mutations are proteintruncating mutations (FitzGerald et al. 1997; Ishioka et al. 1997; Powell et al. 1993; van der Luijt et al. 1994). Although many studies have shown that such methods have technical advantages for saving time and cost (Hogervorst et al. 1995; Ishioka et al. 1997; Powell et al. 1993; van der Luijt et al. 1994), none of the reports evaluated the diagnostic accuracy (sensitivity and specificity) of the methods. According to one report (http://www.nhgri.nih.gov/ELSI/TFGT_final/ index.html), the analytical validity (analytical sensitivity and specificity) of a new genetic test must be assessed by comparing it to the most definitive or "gold standard" method before it is made available for clinical use. In the present study, we focused on a small number of Japanese breast cancer patients with a family history of breast cancer, who have not previously undergone genetic testing. We examined mutations in the $B R C A 1$ and $B R C A 2$ genes both by SC assay and by DNA sequencing (the "gold standard") in a blind manner and compared the methods. We confirmed previous reports indicating that the frequency of $B R C A$ mutations in Japanese patients with familial breast cancer is low (10\%-30\%) (Ikeda et al. 2001; Inoue et al. 1995; Inoue et al. 1997; Takano et al. 1997), and we also showed that the SC assay is sufficiently sensitive and specific to screen protein-truncating mutations in the $B R C A 1$ and
$B R C A 2$ genes, even in a population with a lower frequency of $B R C A$ mutations.

\section{Patients and methods}

\section{Patients}

Twenty-nine patients with a history of breast cancer, who were also from 24 familial breast cancer pedigrees, were selected according to the criteria defined by the Tohoku Familial Cancer Society as having one or more of the following: (1) at least three relatives with breast or ovarian cancer with one being a first-degree relative of the other two; (2) at least two relatives with breast or ovarian cancer who are first-degree relatives of each other and at least one of them should (a) be diagnosed before the age of 40 years, (b) have bilateral breast cancer, or (c) have cancer of other organs; (3) early-onset bilateral breast cancers and at least one cancer diagnosed before the age of 40 years. Informed consent was obtained from all the patients participating in this study. Blood samples were collected, labeled with coded numbers, and analyzed without the patients' clinical information being known to the analyst. Three technicians performed the two genetic analyses; one performed the SC assay and two performed direct DNA sequencing. The patients' clinical information and the results of each assay were not disclosed to the examiners until all assays were complete. Approval was obtained from the Ethics Committee of Tohoku University Graduate School of Medicine for analysis of the $B R C A 1$ and $B R C A 2$ genes.

\section{Extraction of DNA and RNA}

Approximately $2 \times 7 \mathrm{ml}$ of peripheral blood was collected in a 10-ml tube containing RPMI 1640 cell culture medium and transferred to the laboratory at $4^{\circ} \mathrm{C}$. Genomic DNA was extracted directly from $3 \mathrm{ml}$ of the blood using a QIAamp 8 DNA Blood BioRobot Kit (Qiagen, Valencia, CA, USA) equipped with a BioRobot 9604 (Qiagen). We used a MicroFast Track mRNA isolation kit (Invitrogen, Carlsbad, CA, USA) to extract poly $\mathrm{A}^{+} \mathrm{RNA}$ from mononuclear cells (approximately $3 \times 10^{7}$ cells separated from $5 \mathrm{ml}$ blood using a lymphoprep tube) from 14 of the patients. The remaining $7 \mathrm{ml}$ of blood was used to immortalize lymphoblastoid cells using Epstein-Bar virus infection, and these were used for DNA and/or RNA extraction in some cases.

\section{Polymerase chain reaction (PCR)}

First-strand cDNA was synthesized from the poly $\mathrm{A}^{+} \mathrm{RNA}$ using a first-strand cDNA synthesis kit (Pharmacia, Uppsala, Sweden), and this was used to amplify DNA fragments: BRCA1a (0.8kb); BRCA1c (1.6kb) (Ishioka et al. 1997); and BR2a (2.2kb), BR2d (1.9kb), and BR2e (1.9kb) (Fig. 1A). The DNA fragments BRCA1b (3.4kb) (Ishioka et al. 1997), BR2b (2.7kb), BR2c (2.1 kb), and BR2/ex10 (1.1 kb) 
(Fig. 1A) were amplified from genomic DNA. The primers used for amplification of the BRCA1 fragments BRCA1a-c have been described previously (Ishioka et al. 1997). The primers for amplification of the $B R C A 2$ fragments were $5^{\prime}$ ATGCCTATTGGATCCAAAGAGAG-3' and 5' -TGAC $^{\prime}$ AGAGAATCAGCTTCTGGGG-3' for BR2a, 5'-TCTT CTGTGAAAAGAAGCTGTTCAC-3' and 5'-CCCGCT AGCTGTATGAAAACCC-3' for BR2b, 5' -AGAAAGA ACAAAATGGACATTCTAAG-3' and 5'-TTGTTGAA ATTGAGAGAGATATGGAG-3' for BR2c, 5'-TCTGA GCATAGTCTTCACTATTCACCTAC-3' and 5'-TCTT AAGAGGGGAGGATCTAACTGG-3' for BR2d, 5' TACAGATATGATACGGAAATTGATAG-3' and 5'TAAAGGCAGTCTACTCAAGAAATCC-3' for BR2e, and 5'-TATAAAATATTAATGTGCTTCTGTT- ${ }^{\prime}$ ' and 5'-AAGGAATCGTCATCTATAAAACTA-3' for BR2/ ex10. All PCR fragments were obtained using ExTaq or LA Taq DNA polymerase (Takara Shuzo, Tokyo, Japan). Information on the PCR parameters are available at our website (http://www.idac.tohoku.ac.jp/dep/co/data/ saka/brca01.htm).

Plasmids and gap vectors

For the SC assay of $B R C A 2$, six novel plasmids were constructed (Fig. 1B): pCI-BR2a, pCI-BR2b, pCI-BR2c, pCIBR2d, pCI-BR2e, and pCI-BR2/ex10. They were obtained by inserting a PCR-derived cDNA fragment of the $B R C A 2$ containing nucleotide (nt) 1-2130 (the first letter of the initiation codon was defined as nt 1), nt 1921-4587, nt 44116480, nt 6265-8211, nt 7972-9837, and nt 794-1897, into a BamHI site of pCI-HA(URA3)-2 (Ishioka et al. 1997). All plasmids exhibited the $\mathrm{Ura}^{+}$phenotype, confirming an in-frame fusion of each $B R C A 2$ fragment and the yeast $U R A 3$ gene. To make linearized gap vectors, we digested pCI-BR2a，pCI-BR2b，pCI-BR2c，pCI-BR2d，pCI-BR2e, and pCI-BR2/ex10 by the restriction enzymes Pst I/XbaI, XbaI/SpeI, SpeI/PstI, PstI/SpeI, SpeI/NsiI, and SpeI, respectively, and purified them by a GFX PCR DNA and Gel Band Purification Kit (Pharmacia) after separating the longer DNA fragment by agarose gel electrophoresis. The preparation of the gap vectors used for the stop codon assay for $B R C A 1$ has been described previously (Ishioka et al. 1997).

\section{SC assay}

The yeast strain used in this study was YPH499 (MATa, ura3-52, lys2-801amber, ade2-101ocher, trp1 $\Delta 63$, his3 $\Delta 200$, leu2 $\Delta 1$ ) (Stratagene, La Jolla, CA, USA). The preparation of frozen competent cells and the method for transformation has been described previously (Ishioka et al. 1997). In brief, each $B R C A 1$ or BRCA2 PCR fragment ( 200ng) was cotransformed with the corresponding linearized gap vector $(\sim 30 \mathrm{ng})$ and transformants were selected on a synthetic complete medium lacking leucine (SC-Leu). The 25-50 transformants were assayed further for either the $\mathrm{Ura}^{+}$phenotype, by growing them on synthetic complete
A

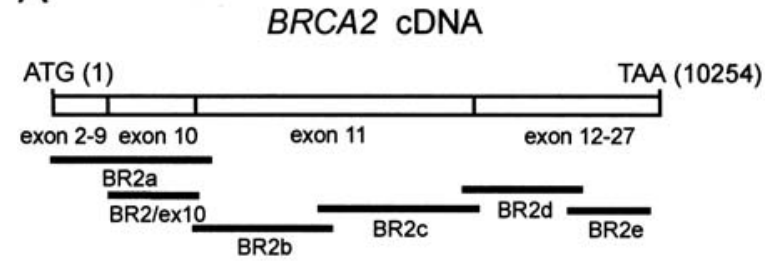

B
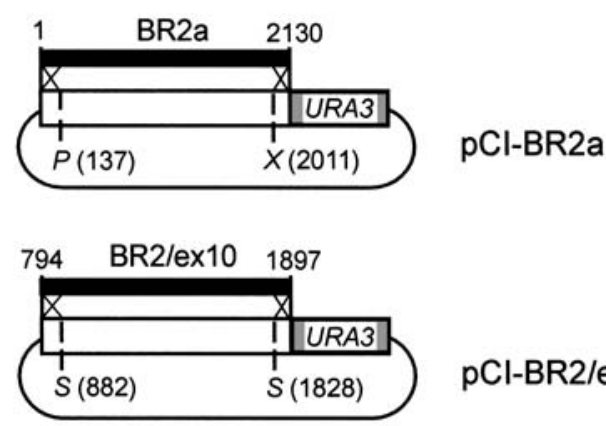

pCl-BR2/ex10
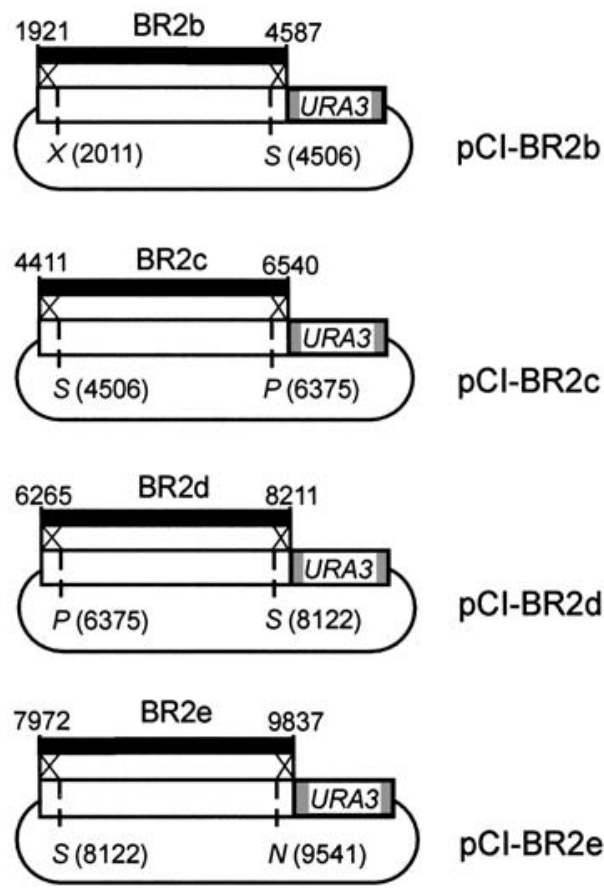

Fig. 1A,B. Schematic representation of the stop codon (SC) assay of the $B R C A 2$ gene. A Sequences of $B R C A 2$ cDNA and six polymerase chain reaction (PCR) fragments were chosen for the SC assay. B Plasmids for the $\mathrm{SC}$ assay of the $B R C A 2$ gene and the corresponding PCR fragments. cDNA (BR2a, BR2d, and BR2e) or genomic DNA (BR2/ex10, BR2b, and BR2c) fragments shown in $\mathbf{A}$ were inserted inframe into the BamHI site of pCI-HA(URA3)-2 (Ishioka et al. 1997), producing plasmids pCI-BR2a, pCI-BR2d, pCI-BR2e, pCI-BR2/ ex10, pCI-BR2b, and pCI-BR2c, respectively. Digestion of the plasmids by the indicated restriction endonucleases removed the central portion of the BRCA2 sequences and generated gap vectors. Cotransformation of a gap vector with a corresponding PCR fragment into yeast recircularizes the plasmid by homologous recombination in vivo. The numbers indicate nucleotide positions downstream of the first nucleotide of ATG in the BRCA2 coding region. P, PstI; X,XhoI; S, SpeI; N, NsiI 
medium that lacked leucine and uracil (SC-Leu-Ura), or for 5FOA resistance, by growing them on synthetic medium containing $5 \mathrm{FOA}(1 \mathrm{mg} / \mathrm{ml})$. If $80 \%$ or more of transformants were $\mathrm{Ura}^{+} / 5 \mathrm{FOA}^{\mathrm{s}}$, the sample was scored as negative for the protein-truncating mutation, indicating a homozygous wild type. If less than $80 \%$ of transformants were $\mathrm{Ura}^{+} / 5 \mathrm{FOA}^{\mathrm{s}}$, we amplified the PCR fragment again and repeated the $\mathrm{SC}$ assay to confirm the final result. If the result showed less than $80 \% \mathrm{Ura}^{+} / 5 \mathrm{FOA}^{\mathrm{s}}$ again, the sample was positive for the presence of the heterozygous proteintruncating mutation.

\section{DNA sequencing}

We sequenced approximately $23.0 \mathrm{~kb}$ of the $B R C A 1$ and $B R C A 2$ genes that contained all the coding exons and their flanking exon-intron boundaries. Except for exon 11 of both the $B R C A$ genes, each coding exon and the flanking intron was amplified with a set of upstream and downstream primers and was sequenced by 1-3 sequence primer(s). Exon 11 of each of the BRCA1 and BRCA2 genes was sequenced using 16 and 18 primers, respectively. All of the primer sequences are listed at our website (http:// www.idac.tohoku.ac.jp/dep/co/data/saka/brca01.htm) and all sequencing reactions were performed using a CEQ DTCS Kit or CEQ DTCS-Quick Start Kit (Beckman Coulter, Fullerton, CA, USA) and a GeneAmp PCR System 9700 (Perkin-Elmer, Norwalk, CT, USA), and then processed by an automated capillary sequencer CEQ2000 or CEQ2000EX (Beckman Coulter).

\section{Results and discussion}

We have described previously the SC assay for the $B R C A 1$ gene and the $A P C$ gene, a gene that is responsible for familial adenomatous polyposis (Ishioka et al. 1997). In the SC assay, a PCR-amplified DNA fragment derived from patient cDNA or genomic DNA was recombined into a specific gap vector harboring the yeast $U R A 3$ gene, and the yeast transformant was selected as a colony using an appropriate selection medium (SC-Leu). The inability to express the URA3-fusion protein depends on the existence of a protein-truncating mutation within the inserted PCR fragment. Therefore, most of the colonies $(\geq 80 \%)$ are able to grow on a medium lacking uracil $\left(\mathrm{Ura}^{+}\right)$when the patient DNA fragment has neither nonsense nor frame-shift mutations. If the patient's DNA contains a heterozygous proteintruncating mutation, approximately half of the colonies cannot grow in the same medium (Ura ${ }^{-}$). So far, the same or a similar yeast-based assay has been applied to other genes (Ishioka et al. 1997; Suzuki et al. 1998).

In this study, we constructed a plasmid system for an SC assay of the BRCA2 gene (Fig. 1B), which divides the open reading frame of the $B R C A 2$ gene into six fragments (Fig. 1A) and inserts each of them into a BamHI fragment of the pCI-HA(URA3)-2 (Ishioka et al. 1997; Suzuki et al. 1998)
(Fig. 1B). When these plasmids are introduced into $\mathrm{ura}^{-}$ yeast cells, the yeast cells can be positively selected on the plate lacking uracil $\left(\mathrm{Ura}^{+}\right)$or negatively selected on the plate containing 5FOA $\left(5 \mathrm{FOA}^{\mathrm{s}}\right.$ ) (data not shown). These vectors were digested by one or two restriction endonucleases (Fig. 1B) and used as gap vectors. We confirmed previously that cotransformation of each of the gap vectors with corresponding PCR fragments with or without a known protein-truncating mutation resulted in a $\mathrm{Ura}^{-} /$ $5 \mathrm{FOA}^{\mathrm{R}}$ or $\mathrm{Ura}^{+} / 5 \mathrm{FOA}^{\mathrm{S}}$ yeast phenotype, respectively.

\section{Screening protein-truncating mutations by SC assay}

Using the SC assay of $B R C A 1$ (Ishioka et al. 1997) and $B R C A 2$ (earlier), we screened a total of nine fragments covering the coding sequences of both $B R C A 1$ (three fragments) and $B R C A 2$ (six fragments) in 29 breast cancer patients (24 families) whose BRCA status had not been examined. A technician who was not informed about the patients' clinical background and the results of the DNA sequencing performed the SC assay. In 12 cases, both genomic DNA and RNA were available and, therefore, we examined all nine DNA fragments. In the remaining 17 cases, we examined only four (BR1b, BR2/ex10, BR2b, and BR2c) fragments that covered approximately $57 \%$ of the coding sequences (Fig. 1A) because RNA was not available and it was impossible to perform reverse transcriptase (RT)-PCR to amplify the remaining fragments. Among the 176 fragments we analyzed, the majority (172) were negative for the SC assay; $80 \%$ or more of the colonies were $\mathrm{Ura}^{+}($mean $\pm \mathrm{SD}=90.0 \pm 6.5 \%)$, which showed that there were no protein-truncating mutations in these fragments (Fig. 2A). The remaining four fragments that were derived from different patients were positive for the SC assay because a significantly lower number of $\mathrm{Ura}^{+}$colonies were found $\left(\mathrm{Ura}^{+}\right.$fraction $<80 \%$ ) (Fig. 2A). To confirm the results, we reexamined the $\mathrm{SC}$ assay using independently amplified PCR fragments. Three of the four fragments (cases BR007, BR005, and BR001) again were positive, and, therefore, were thought to have retained a proteintruncating mutation within each fragment. Representative results are shown in Fig. 2B. The remaining fragment, which was derived from cDNA (BR2a fragment) and previously had a $72 \% \mathrm{Ura}^{+}$fraction, had a negative score $(88 \%)$ in the second experiment. Although we did not pursue the cause of low fidelity in this case, we had found previously that the RT reaction sometimes caused unexpectedly lower fidelity and that this issue was usually resolved by repeating the experiment. Therefore, we concluded finally that the BR2a fragment was negative for the SC assay. Because, in general, it is impossible to check and control the quality of RNA strictly, we stress that the repeat analysis and confirmation of the mutations by DNA sequence analysis are important, especially when the PCR fragment is derived from RT-PCR and the $\mathrm{Ura}^{+}$fraction is close to the cut-off value $(80 \%)$. So far, $424 B R C A 1$ or BRCA2 fragments have been screened using the SC assay, and the $\mathrm{Ura}^{+}$fraction (mean $\pm \mathrm{SD}$ ) was $52.4 \pm 8.9 \%(n=17)$ or $89.3 \pm 7.1 \%(n=407)$ in fragments 


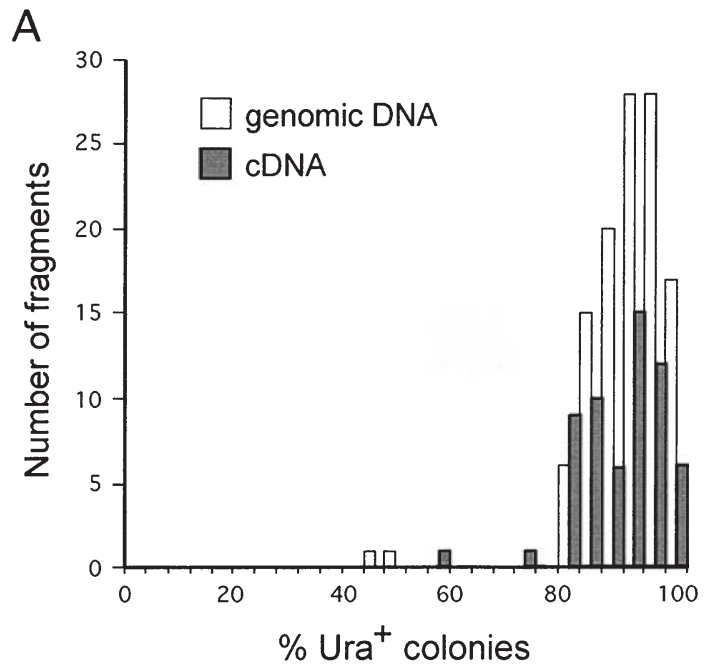

B

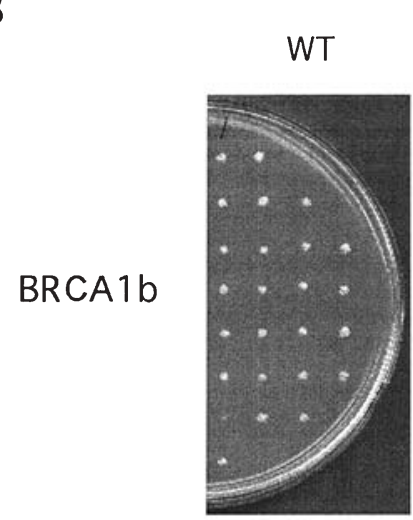

$96 \%$

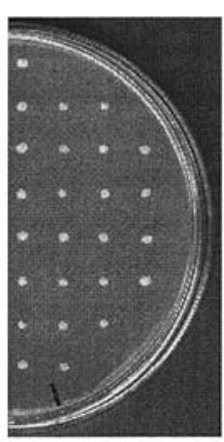

$100 \%$

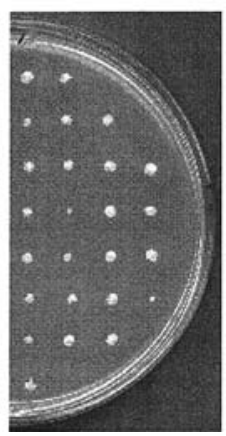

$96 \%$ heterozygous

mutant

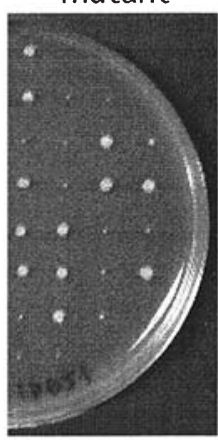

$48 \%$

2389-2390delGA
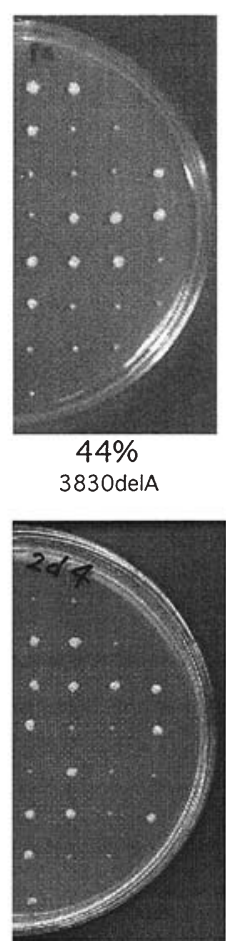

$56 \%$

6491-6495delAGTTG with or without a heterozygous mutation. To evaluate the cut-off value $(80 \%)$ of the SC assay, we drew the ROC (receiver operating characteristic) plots (Zweig and Campbell 1993) based on the individual data of this study. The plots indicated that any values from $60 \%$ to $80 \%$ of the rational cut-off value warranted good sensitivity $(=1.00)$ and specificity $(>0.99)$. Therefore, the value of $80 \%$ should be a reasonable cut-off value and may minimize possible false-negative cases in future studies.

Detection of sequence variations in the coding sequences by direct DNA sequencing

To confirm the sequence variations, we sequenced the fulllength coding sequences and the flanking introns of the $B R C A 1$ and $B R C A 2$ genes using genomic DNA in all of the cases by automated direct sequencing, a standard method for mutation detection. Two technicians who were blind to the patients' clinical backgrounds and the results of the $\mathrm{SC}$ assay performed the DNA sequencing. We found five protein-truncating mutations, including three frameshift mutations (2389-2390delGA in exon 11 of BRCA1, 3830delA in exon 11 of $B R C A 2$, and 6491-6495delAGTTG in exon 11 of $B R C A 2$ ) and two nonsense mutations (C1372X in exon 12 of BRCA1 and S2835X in exon 20 of $B R C A 2$ ) (Table 1). During the sequencing analysis, we also found 40 other sequence variants (16 in BRCA1 and 24 in $B R C A 2)$ within the coding regions and their flanking introns (data not shown). We concluded that most of these variants are common polymorphisms because they are found repeatedly in other patients and because some of them have been reported in an SNP database. However, they also contain 12 SNPs (5 in BRCA1 and 7 in BRCA2) that were found only once in this study and not reported previously (Table 1). In the case of the five SNPs that substitute a single amino acid, there is a possibility that they contain pathogenic missense mutations, but there is no reliable functional assay at present.

Diagnostic accuracy of the SC assay for detecting protein-truncating mutations

To examine the diagnostic accuracy of the SC assay, we compared the results of the SC assay with the DNA sequencing data (Fig. 3). We found no protein-truncating

Fig. 2A,B. Distribution of $\mathrm{Ura}^{+}$fractions $\left(\mathrm{Ura}^{+}\right.$colonies/total colonies assayed). A The result of the SC assay of both BRCA1 and BRCA2 genes is shown for a total of 176 fragments derived from specimens (116 genomic DNA and 60 cDNA) of this study. B Representative results of the SC assay showing heterozygous mutations. Right panel, The yeast transformants ( 25 clones) derived from the BR1b fragment of cases BR007 (top), BR2b fragment of BR005 (middle), and BR2d fragment of BR001 (bottom) were evaluated for their ability to grow in synthetic media lacking uracil. Approximately one half of the transformants $(44 \%-56 \%)$ did not grow. A specific mutation shown under each panel was finally detected by DNA sequencing. Left panel, Negative controls for the corresponding DNA fragments derived from patients without any protein-truncating mutation. More than $80 \%$ of colonies grew. WT, Wild type 
Table 1. Sequence variants (polymorphism and mutation) of $B R C A 1$ and $B R C A 2$ genes

\begin{tabular}{|c|c|c|c|c|c|}
\hline Case number & Allele ID & Location & Nucleotide change & Sequence $\left(5^{\prime}\right.$ to $\left.3^{\prime}\right)$ & Interpretation \\
\hline \multicolumn{6}{|c|}{5 protein-truncating mutations } \\
\hline BR007 & BRCA1-7 & Exon 11 & 2389-2390delGA & ggcaaaaaca GA/-accaaataaa & Frame-shift mutation \\
\hline BR017 & BRCA1-11 & Exon 12 & $4116 \mathrm{~T}>\mathrm{A}$ & catctgggtg T/A gagagtgaaa & Nonsense mutation $(\mathrm{C} 1372 \mathrm{X})$ \\
\hline BR005 & BRCA2-18 & Exon 11 & 3830delA & aagatagaaa $\mathrm{A} /$ - tcataatgat & Frame-shift mutation \\
\hline BR001 & BRCA2-22 & Exon 11 & 6491-6495delAGTTG & gacaaacaac AGTTG/- gtattaggaa & Frame-shift mutation \\
\hline BR018 & BRCA2-26 & Exon 20 & $8504 \mathrm{C}>\mathrm{A}$ & gagaagacat $\mathrm{C} / \mathrm{A}$ atctggatta & Nonsense mutation (S2835X) \\
\hline \multicolumn{6}{|c|}{12 sequence variations found once in this study } \\
\hline BR028 & BRCA1-4 & Exon 11 & $814 \mathrm{G}>\mathrm{A}$ & gagccatgtg G/A cacaaatact & G275D \\
\hline BR027 & BRCA1-13 & Intron 14 & IVS14+14A $>$ G & agaaacatca $\mathrm{A} / \mathrm{G}$ tgtaaagatg & Close to exon-intron boundary \\
\hline BR013 & BRCA1-15 & Exon 16 & $4883 \mathrm{~T}>\mathrm{C}$ & tataatgcaa $\mathrm{T} / \mathrm{C}$ ggaagaaagt & M1628T \\
\hline BR027 & BRCA1-17 & Intron 22 & $\operatorname{IVS} 22+31 \mathrm{~A}>\mathrm{T}$ & gagagggagg $\mathrm{A} / \mathrm{T}$ cacaatattc & Close to exon-intron boundary \\
\hline BR006 & BRCA1-18 & Intron 23 & IVS $23+8 \mathrm{G}>\mathrm{T}$ & atggtaaggt $\mathrm{G} / \mathrm{T}$ cctgcatgta & Close to exon-intron boundary \\
\hline BR017 & BRCA2-2 & Intron 2 & IVS2-16T $>A$ & taaggtggga T/A ttttttttta & Close to exon-intron boundary \\
\hline BR026 & BRCA2-3 & Intron 2 & IVS2-9T $>$ G & ggattttttt $\mathrm{T} / \mathrm{G}$ ttaaatagat & Close to exon-intron boundary \\
\hline BR028 & BRCA2-8 & Exon 10 & $798 \mathrm{~T}>\mathrm{C}$ & gtcatggatt $\mathrm{T} / \mathrm{C}$ ggaaaaacat & F266 silent \\
\hline BR025 & BRCA2-12 & Exon 10 & $1744 \mathrm{~A}>\mathrm{C}$ & tttaatatcc $\mathrm{A} / \mathrm{C}$ ctttgaaaaa & $\mathrm{T} 582 \mathrm{P}$ \\
\hline BR020 & BRCA2-17 & Exon 11 & $3420 \mathrm{~T}>\mathrm{C}$ & tgcagaagag $\mathrm{T} / \mathrm{C}$ acatttgaag & S1140 silent \\
\hline BR023 & BRCA2-19 & Exon 11 & $4566 \mathrm{G}>\mathrm{T}$ & ctactctgtt $\mathrm{G} / \mathrm{T}$ ggttttcata & L1522F \\
\hline BR030 & BRCA2-20 & Exon 11 & $6131 \mathrm{G}>\mathrm{T}$ & tcccaaaag $\mathrm{G} / \mathrm{T}$ cttttcatat & G2044V \\
\hline
\end{tabular}

\section{direct DNA sequencing}

(protein-truncating mutation)

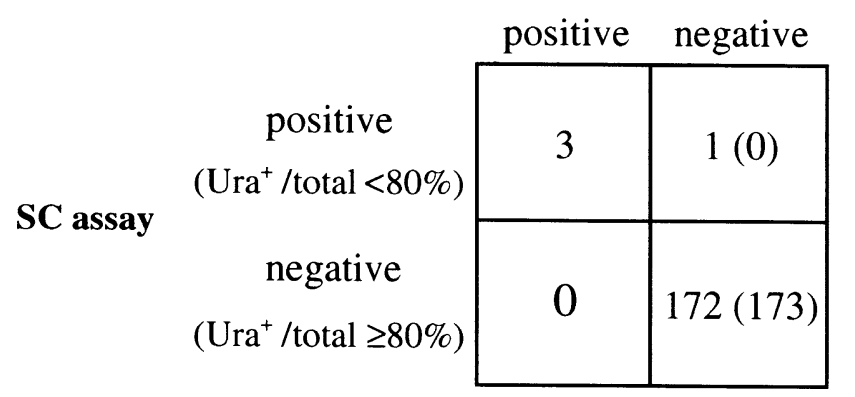

Fig. 3. Diagnostic accuracy of the SC assay for detection of proteintruncating mutations in both $B R C A 1$ and $B R C A 2$ genes. The results of the SC assay were compared with that of direct DNA sequencing. Values in the box indicate the number of fragments used in the SC assay. Values in parentheses indicate the results after reassay of fragments that were positive in the first screening

mutation in the DNA sequences of the 172 fragments that were negative for the SC assay, indicating that the negative predictive value was $100 \%$. Of the remaining four fragments that were positive for the SC assay, three fragments contained protein-truncating mutations (Fig. 2B, Table 1). Only one fragment that was positive in the first screening had no protein-truncating mutation (false-positive case), but this was eventually scored as negative after repeating the assay (see earlier). Among the five protein-truncating mutations detected by DNA sequencing, two mutations could not be compared with the SC assay because no RNA was available. Therefore, the SC assay detected all proteintruncating mutations within the examined DNA fragments (sensitivity, 100\%). Because there was one false-positive case in the first screening, the specificity of the assay was $99 \%$ (172 of 173) but the value finally became $100 \%$. These results indicate that the SC assay is sufficiently sensitive and specific to screen protein-truncating mutations of the
$B R C A 1$ and the $B R C A 2$ genes, even in a population that contains small fractions of $B R C A$ mutations.

We have reported previously on the analytical validity of the SC assay for the $B R C A 1$ gene using blood samples with or without known $B R C A 1$ truncating mutations, and we have also discussed the technical advantages of the SC assay over the PTT (Ishioka et al. 1997). In this study, we expanded the application of the SC assay to the $B R C A 2$ gene, and confirmed the diagnostic accuracy of the SC assay for both $B R C A 1$ and $B R C A 2$ genes by analyzing specimens with unknown $B R C A$ status in a blind manner. Once an examined specimen is positive in the SC assay, only 0.8 $3.4 \mathrm{~kb}$ DNA sequencing is needed to detect a proteintruncating mutation. We conclude that the SC assay is a useful and reliable screening method to detect pathogenic protein-truncating mutations in both $B R C A$ genes. Apart from the technical advantages, we also note that the SC assay has an economical advantage. We have calculated the net cost (labor cost not included) for detecting proteintruncating mutations with or without the use of the SC assay. The cost of the SC assay for screening plus DNA sequencing only for $\mathrm{SC}$ assay-positive fragments was significantly lower than that for full-length DNA sequencing in all specimens; e.g., if the fraction of BRCA-truncating mutation is $20 \%$ in a population, the former costs only $11.4 \%$ of the latter. The advantage of the SC assay over the PTT should be validated by comparing the two assays in a large number of clinical samples.

We also showed that the frequency of the $B R C A 1$ and $B R C A 2$ gene mutations in our Japanese familial breast cancer patients was similar to that among similar patients in Western countries, which confirms previous reports (Ikeda et al. 2001; Inoue et al. 1995; Inoue et al. 1997; Takano et al. 1997). However, care should be taken in interpreting the data because there were some differences, for example, the number of breast cancer patients in the families of the two populations. Furthermore, there may be mutations that could not be detected by the current screening system and 
DNA sequencing, such as a largely deleted mutant allele that has been observed in other ethnic populations (PetrijBosch et al. 1997; Puget et al. 1999a; Puget et al. 1999b; Puget et al. 1997; Swensen et al. 1997), and that could not be described as missense mutations because there is no functional assay available. In fact, it has been reported that at least $10 \%-15 \%$ of deleterious $B R C A 1$ mutations are missense mutations. These issues need to be resolved by developing other methods, including a reliable, rapid, and accurate functional assay.

Acknowledgments We are grateful to our patients for participating in this study and we thank all of the physicians who provided clinical samples. We also wish to thank Yuka Fujimaki for technical assistance.

\section{References}

Anglian Breast Cancer Study Group (2000) Prevalence and penetrance of $B R C A 1$ and $B R C A 2$ mutations in a population-based series of breast cancer cases. Br J Cancer 83:1301-1308

Easton DF, Bishop DT, Ford D, Crockford GP (1993) Genetic linkage analysis in familial breast and ovarian cancer: results from 214 families. The Breast Cancer Linkage Consortium. Am J Hum Genet 52:678-701

FitzGerald MG, Bean JM, Hegde SR, Unsal H, MacDonald DJ, Harkin DP, Finkelstein DM, Isselbacher KJ, Haber DA (1997) Heterozygous $A T M$ mutations do not contribute to early onset of breast cancer. Nat Genet 15:307-310

Ford D, Easton DF, Stratton M, Narod S, Goldgar D, Devilee P, Bishop DT, Weber B, Lenoir G, Chang-Claude J, Sobol H, Teare MD, Struewing J, Arason A, Scherneck S, Peto J, Rebbeck TR, Tonin P, Neuhausen S, Barkardottir R, Eyfjord J, Lynch H, Ponder BA, Gayther SA, Zelada-Hedman M, The Breast Cancer Linkage Consortium (1998) Genetic heterogeneity and penetrance analysis of the $B R C A 1$ and $B R C A 2$ genes in breast cancer families. Am $\mathrm{J}$ Hum Genet 62:676-689

Hogervorst FB, Cornelis RS, Bout M, van Vliet M, Oosterwijk JC, Olmer R, Bakker B, Klijn JG, Vasen HF, Meijers-Heijboer H, Menko FH, Cornelisse CJ, den Dunnen JT, Devilee P, van Ommen GJ (1995) Rapid detection of BRCA1 mutations by the protein truncation test. Nat Genet 10:208-212

Ikeda N, Miyoshi Y, Yoneda K, Shiba E, Sekihara Y, Kinoshita M, Noguchi S (2001) Frequency of $B R C A 1$ and $B R C A 2$ germline mutations in Japanese breast cancer families. Int J Cancer 91:83-88

Inoue R, Fukutomi T, Ushijima T, Matsumoto Y, Sugimura T, Nagao M (1995) Germline mutation of BRCA1 in Japanese breast cancer families. Cancer Res 55:3521-3524

Inoue R, Ushijima T, Fukutomi T, Fukami A, Sugimura H, Inoue $\mathrm{S}$, Okonogi H, Sugimura T, Matsumoto Y, Nagao M (1997) BRCA2 germline mutations in Japanese breast cancer families. Int J Cancer 74:199-204

Ishioka C, Suzuki T, FitzGerald M, Krainer M, Shimodaira H, Shimada A, Nomizu T, Isselbacher KJ, Haber D, Kanamaru R (1997) Detection of heterozygous truncating mutations in the BRCA1 and $A P C$ genes by using a rapid screening assay in yeast. Proc Natl Acad Sci USA 94:2449-2453

Kuklin A, Munson K, Gjerde D, Haefele R, Taylor P (1997) Detection of single-nucleotide polymorphisms with the WAVE DNA fragment analysis system. Genet Test 1:201-206

Mazoyer S, Dunning AM, Serova O, Dearden J, Puget N, Healey CS, Gayther SA, Mangion J, Stratton MR, Lynch HT, Goldgar DE, Ponder BA, Lenoir GM (1996) A polymorphic stop codon in BRCA2. Nat Genet 14:253-254

Miki Y, Swensen J, Shattuck-Eidens D, Futreal PA, Harshman K, Tavtigian S, Liu Q, Cochran C, Bennett LM, Ding W, Bell R, Rosenthal J, Hussey C, Tran T, McClure M, Frye C, Hattier T, Phelps R, Haugen-Strano A, Katcher H, Yakumo K, Gholami Z, Shaffer D, Stone S, Bayer S, Wray C, Bogden R, Dayananth P, Ward J, Tonin P, Narod S, Bristow PK, Norris FH, Helvering L, Morrison
P, Rosteck P, Lai M, Barrett JC, Lewis C, Neuhausen S, CannonAlbright L, Goldgar D, Wiseman R, Kamb A, Skolnick MH (1994) A strong candidate for the breast and ovarian cancer susceptibility gene BRCA1. Science 266:66-71

Narod SA, Ford D, Devilee P, Barkardottir RB, Lynch HT, Smith SA, Ponder BA, Weber BL, Garber JE, Birch JM, Cornelis RS, Kelsell DP, Spurr NK, Smyth E, Haites N, Sobol H, Bignon Y, Chang-Claude J, Hamann U, Lindblom A, Borg A, Piver MS, Gallion HH, Struewing JP, Whittemore A, Tonin P, Goldgar DE, Easton DF, The Breast Cancer Linkage Consortium (1995) An evaluation of genetic heterogeneity in 145 breast-ovarian cancer families. Am J Hum Genet 56:254-264

Neuhausen SL (1999) Ethnic differences in cancer risk resulting from genetic variation. Cancer 86:2575-2582

Orita M, Iwahana H, Kanazawa H, Hayashi K, Sekiya T (1989) Detection of polymorphisms of human DNA by gel electrophoresis as single-strand conformation polymorphisms. Proc Natl Acad Sci USA 86:2766-2770

Petrij-Bosch A, Peelen T, van Vliet M, van Eijk R, Olmer R, Drusedau M, Hogervorst FB, Hageman S, Arts PJ, Ligtenberg MJ, MeijersHeijboer H, Klijn JG, Vasen HF, Cornelisse CJ, van't Veer LJ, Bakker E, van Ommen GJ, Devilee P (1997) BRCA1 genomic deletions are major founder mutations in Dutch breast cancer patients. Nat Genet 17:341-345

Powell SM, Petersen GM, Krush AJ, Booker S, Jen J, Giardiello FM, Hamilton SR, Vogelstein B, Kinzler KW (1993) Molecular diagnosis of familial adenomatous polyposis. N Engl J Med 329:1982-1987

Puget N, Torchard D, Serova-Sinilnikova OM, Lynch HT, Feunteun J, Lenoir GM, Mazoyer S (1997) A 1-kb Alu-mediated germ-line deletion removing $B R C A 1$ exon 17. Cancer Res 57:828-831

Puget N, Sinilnikova OM, Stoppa-Lyonnet D, Audoynaud C, Pages S, Lynch HT, Goldgar D, Lenoir GM, Mazoyer S (1999a) An Alumediated 6-kb duplication in the BRCA1 gene: a new founder mutation? Am J Hum Genet 64:300-302

Puget N, Stoppa-Lyonnet D, Sinilnikova OM, Pages S, Lynch HT, Lenoir GM, Mazoyer S (1999b) Screening for germ-line rearrangements and regulatory mutations in $B R C A 1$ led to the identification of four new deletions. Cancer Res 59:455-461

Rebbeck TR (1999) Inherited genetic predisposition in breast cancer. A population-based perspective. Cancer 86:2493-2501

Shih HA, Couch FJ, Nathanson KL, Blackwood MA, Rebbeck TR, Armstrong KA, Calzone K, Stopfer J, Seal S, Stratton MR, Weber BL (2002) BRCA1 and BRCA2 mutation frequency in women evaluated in a breast cancer risk evaluation clinic. J Clin Oncol 20:994-999 Struewing JP, Hartge P, Wacholder S, Baker SM, Berlin M, McAdams M, Timmerman MM, Brody LC, Tucker MA (1997) The risk of cancer associated with specific mutations of BRCA1 and BRCA2 among Ashkenazi Jews. N Engl J Med 336:1401-1408

Suzuki T, Ishioka C, Kato S, Mitachi Y, Shimodaira H, Sakayori M, Shimada A, Asamura M, Kanamaru R (1998) Detection of APC mutations by a yeast-based protein truncation test (YPTT). Genes Chromosomes Cancer 21:290-297

Swensen J, Hoffman M, Skolnick MH, Neuhausen SL (1997) Identification of a $14 \mathrm{~kb}$ deletion involving the promoter region of $B R C A 1$ in a breast cancer family. Hum Mol Genet 6:1513-1517

Szabo CI, King MC (1997) Population genetics of BRCA1 and BRCA2. Am J Hum Genet 60:1013-1020

Takano M, Aida H, Tsuneki I, Takakuwa K, Hasegawa I, Tanaka H, Saito M, Tsuji S, Sonoda T, Hatae M, Chen JT, Takahashi K, Hasegawa K, Toyoda N, Saito N, Yakushiji M, Araki T, Tanaka K (1997) Mutational analysis of BRCA1 gene in ovarian and breastovarian cancer families in Japan. Jpn J Cancer Res 88:407-413

Tavtigian SV, Simard J, Rommens J, Couch F, Shattuck-Eidens D, Neuhausen S, Merajver S, Thorlacius S, Offit K, Stoppa-Lyonnet D, Belanger C, Bell R, Berry S, Bogden R, Chen Q, Davis T, Dumont M, Frye C, Hattier T, Jammulapati S, Janecki T, Jiang P, Kehrer R, Leblanc JF, Mitchell JT, McArthur-Morrison J, Nguyan K, Peng Y, Samson C, Schroeder M, Synder SC, Steele L, Stringfellow M, Stroup C, Swedlund B, Swensen J, Teng D, Thomas A, Tran T, Tran $\mathrm{T}$, Tranchant M, Weaver-Feldhaus J, Wong AKC, Shizuya H, Eyfjord JE, Cannon-Albright L, Labrie F, Skolnick MH, Weber B, Kamb A, Goldgar DE (1996) The complete BRCA2 gene and mutations in chromosome 13q-linked kindreds. Nat Genet 12:333-337

Thorlacius S, Struewing JP, Hartge P, Olafsdottir GH, Sigvaldason H, Tryggvadottir L, Wacholder S, Tulinius H, Eyfjord JE (1998) 
Population-based study of risk of breast cancer in carriers of $B R C A 2$ mutation. Lancet 352:1337-1339

van der Luijt R, Khan PM, Vasen H, van Leeuwen C, Tops C, Roest P, den Dunnen J, Fodde R (1994) Rapid detection of translationterminating mutations at the adenomatous polyposis coli $(A P C)$ gene by direct protein truncation test. Genomics 20:1-4

Wooster R, Bignell G, Lancaster J, Swift S, Seal S, Mangion J, Collins N, Gregory S, Gumbs C, Micklem G (1995) Identification of the breast cancer susceptibility gene BRCA2. Nature 378:789792

Xiao W, Oefner PJ (2001) Denaturing high-performance liquid chromatography: a review. Hum Mutat 17:439-474

Zweig MH, Campbell G (1993) Receiver-operating characteristic (ROC) plots: a fundamental evaluation tool in clinical medicine. Clin Chem 39:561-577 